\title{
Middle-Range Theory for the Nursing Diagnosis of Low Self-Efficacy in Health
}

\author{
Teoría de Rango Medio para el Diagnóstico de Enfermería Baja Autoeficacia en Salud \\ Teoria de Médio Alcance para o Diagnóstico de Enfermagem Baixa Autoeficácia em Saúde
}

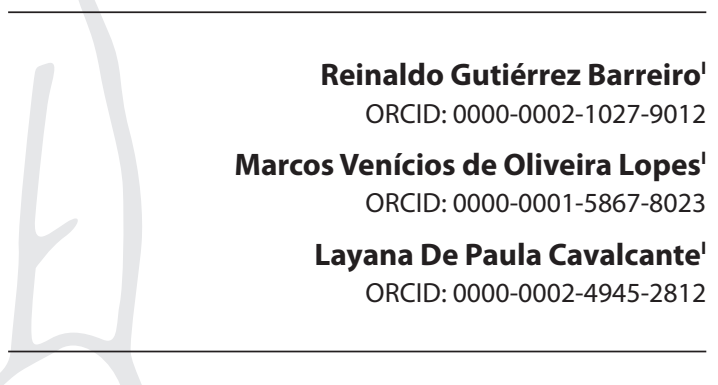

'Universidade Federal do Ceará. Fortaleza, Ceará, Brazil.

How to cite this article:

Barreiro RG, Lopes MVO, Cavalcante LP. Middle-Range Theory for the Nursing Diagnosis of Low Self-Efficacy in Health. Rev Bras Enferm. 2020;73(5):e20190370. doi: http://dx.doi.org/10.1590/0034-7167-2019-0370

Corresponding author:

Reinaldo Gutiérrez Barreiro

E-mail: gutrey@gmail.com

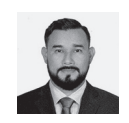

EDITOR IN CHIEF: Antonio José de Almeida Filho ASSOCIATE EDITOR: Rafael Silva

Submission: 08-06-2019 Approval: 11-01-2019

\begin{abstract}
Objectives: theoretical validation of the concept of low self-efficacy in health as a nursing diagnosis construct. Methods: construction of a middle-range theory for validating diagnoses, comprised of five stages: definition of the approach for building the theory; definition of the main concepts; creation of a pictorial diagram; formulation of proposals; establishment of causal relationships and evidence for clinical practice. The main concepts were identified through a literature review and the studies were taken from the LILACS, SCOPUS, CINAHL and PubMed/MEDLINE databases. The final sample was comprised of 92 articles. Results: eighteen etiological factors and 16 clinical indicators were identified; characterized as antecedents and manifestations for inferring a diagnosis of low selfefficacy in health. Conclusions: the related concepts of the new nursing diagnosis of low self-efficacy in health, to be applied in clinical nursing practice, were identified and defined. Descriptors: Nursing; Nursing Theory; Nursing Diagnosis; Self-Efficacy; Health.
\end{abstract}

\section{RESUMEN}

Objetivos: validación teórica del concepto de baja autoeficacia en salud como un constructo diagnóstico de enfermería Métodos: construcción de una teoría de rango medio para validación de diagnósticos que comprende cinco etapas: definición del abordaje de construcción de la teoría, definición de los conceptos principales, construcción de un pictograma, formulación de proposiciones, establecimiento de las relaciones de causalidad y la evidencia para la práctica. Los conceptos principales fueron descritos por medio de una revisión de literatura. Los estudios fueron tomados de las bases de datos LILACS, SCOPUS, CINAHL y PubMed/MEDLINE. Obteniendo la muestra final de 92 artículos. Resultados: se identificaron dieciocho factores etiológicos y dieciséis indicadores clínicos; caracterizados en antecedentes y las manifestaciones para la inferencia diagnóstica de baja autoeficacia en salud. Conclusiones: se identificaron y definieron los conceptos relacionados del nuevo diagnóstico de enfermería de baja autoeficacia en salud, para ser aplicados en la práctica clínica de enfermería.

Descriptores: Enfermería; Teoría de Enfermería; Diagnóstico de Enfermería; Autoeficacia; Salud.

\section{RESUMO}

Objetivo: validação teórica do conceito de baixa autoeficácia em saúde como um construto diagnóstico de enfermagem. Métodos: construção de uma teoria de médio alcance para validação de diagnósticos compreendendo cinco etapas: definição da abordagem para a construção de teoria, definição de conceitos-chaves, construção de um diagrama pictórico, formulação de proposições, estabelecimento de relações causais e evidências para a prática. Os principais conceitos foram descritos por meio de uma revisão de literatura. Os estudos foram retirados das bases de dados LILACS, SCOPUS, CINAHL e PubMed/MEDLINE obtendo uma amostra final de 92 artigos. Resultados: foram identificados dezoito fatores etiológicos e dezesseis indicadores clínicos, caracterizados em antecedentes e as manifestações para a inferência diagnóstica de baja autoeficácia em saúde. Conclusões: foram identificados e definidos os conceitos relacionados ao novo diagnóstico de enfermagem de baixa autoeficácia em saúde a ser aplicado na prática clínica de enfermagem.

Descritores: Enfermagem; Teoria da Enfermagem; Diagnóstico de Enfermagem; Autoeficácia; Saúde. 


\section{INTRODUCTION}

Self-efficacy is defined as "people's judgments of their capabilities to organize and execute courses of action required to attain designated types of performances"(1). This is the primary concept of Bandura's social cognitive theory, which is based on confidence, motivation and learning. Therefore, self-efficacy rests on the assumption that people have influence over their behavior, through reflective thinking, generative use of knowledge and application of skills to perform a specific action ${ }^{(2)}$.

This construct has been amply discussed in the literature by health disciplines, particularly nursing, to understand the behavior adopted by people facing a pathological process. It has been empirically proven that it is a concept that influences the ability to effectively carry out activities to preserve and restore adequate health ${ }^{(3)}$. Some authors have demonstrated that the level of self-efficacy is tied to the adoption of behaviors that promote well-being. For example, people with a high level of self-efficacy have better control over cardiovascular risk factors $^{(4)}$. They also have a higher degree of response to treatments and adherence to therapeutic regimens ${ }^{(5)}$.

Similarly, the evidence indicates that a low level of self-efficacy is associated with increased anxiety and stress ${ }^{(6)}$, which are factors that negatively affect the perception of patients in relation to their ability to engage in self-care activities, since they consider them to be very difficult goals beyond their reach ${ }^{(7)}$.

Consequently, levels of self-efficacy in health behaviors are correlated with people's knowledge of their ability and motivation to adopt the necessary behaviors for attaining an adequate level of well-being ${ }^{(8)}$. Thus, self-efficacy is a determinant for acquiring knowledge and skills ${ }^{(9)}$ and putting into practice the lifestyle changes people need to adopt when confronting a pathological process ${ }^{(10)}$. It is also a determinant for upholding and maintaining recommendations given by nursing professionals ${ }^{(5)}$, which demonstrates that it is a significant predictor of health behaviors ${ }^{(10)}$.

Even though this concept has been extensively investigated in a number of important studies and approached using different research methodologies, it is important to establish that no validation of self-efficacy as a diagnostic construct for nursing has been reported thus far in the existing literature. This shows that it is necessary and pertinent to conceptually and clinically validate the concept of self-efficacy within a nursing diagnosis classification, since it is important to standardize nursing language for professional practice. Therefore, the structuring of a diagnostic construct based on the motivation and conviction of patients regarding their ability to carry out actions that restore their health can guide the actions of nursing professionals and the decision-making process for establishing quality nursing care.

\section{OBJECTIVES}

To validate a diagnostic construct based on the concept of self-efficacy in health, for possible incorporation in the international classification of nursing diagnoses of NANDA International (NANDA-I). This concept will be based on the context of factors that lead patients not to feel motivated or confident in their ability to carry out certain tasks or activities to restore their health, characterized as low self-efficacy in health.

\section{METHODS}

To validate the concept of self-efficacy as a nursing diagnosis construct, a middle-range theory will be used to translate the broad concepts of the theoretical bases into practice. It consists of a smaller number of more concrete concepts and analyzes their possible causal relationships, to facilitate understanding the manifestation of a phenomenon ${ }^{(11-12)}$. It is a methodology that can be used to guide studies that seek to validate concepts and content of new nursing diagnoses ${ }^{(13-14)}$. The specific methodology for identifying the effects of one or more concepts and their causal relationships in a particular diagnosis is comprised of five pre-established stages: definition of the approach for building the theory; definition of the main concepts; construction of a pictorial diagram; formulation of proposals; establishment of causal relationships and evidence for clinical practice.

\section{Definition of the approach for building the theory}

The middle-range theory was implemented through an analysis of the elements that make up the concept of self-efficacy in the health context. To achieve this objective, elements of clinical reasoning, diagnostic validation models and clinical-epidemiological aspects were applied to identify the elements involved in the manifestation of a change in self-efficacy, specifically the phenomenon of low selfefficacy, as well as concepts and causal relationships. This will enable nurses to detect this clinical manifestation in patients under their care ${ }^{(13)}$.

The middle-range theory of low self-efficacy in health was built through studying the conceptual elements of Bandura's social cognitive theory and analysis of research findings through an integrative literature review, based on the following core question: What elements are associated with the clinical manifestation of a low level of self-efficacy in health? Based on this question, the available literature in the following databases was reviewed: Latin American \& Caribbean Health Sciences Literature (LILACS), SCOPUS, Cumulative Index to Nursing and Allied Health Literature (CINAHL) and National Library of Medicine National Institutes of Health (PubMed/MEDLINE). The controlled keywords were selected from the Medical Subject Headings (MeSH), Descriptores en Ciencias de la Salud (DeC) and CINAHL Subject Headings: nursing diagnoses, health, health behaviors and related chronic diseases through the Boolean operator AND with the keyword self-efficacy.

The articles were filtered using the following criteria: primary and secondary studies developed with the concept of self-efficacy in patients who received care in any clinical environment, regardless of age, sex, ethnic origin and comorbidities, published from 2008 to 2018 and written in English, Portuguese or Spanish; editorials and letters to the reader were excluded.

To ensure the quality of the articles chosen and to avoid selection bias, at least two reviewers independently verified all the studies. The assessment to include the study or not was based on an initial reading of the title and abstract. If the two reviewers disagreed on the selection of a study, it was resolved through the participation of a third reviewer.

The full text of the selected articles was then evaluated to ensure that the studies complied with the inclusion criteria. Data from the selected studies was extracted based on the goal of identifying the presence of elements that could help understand and structure the definition as a diagnostic construct of low self-efficacy in health and its 
associated aspects. Studies were excluded whose main concept was not self-efficacy, as well as those that did not address the core question.

\section{Definition of the main concepts}

The key concepts addressed in the literature review were the conceptual elements of Bandura's social cognitive theory and concepts found during the literature review. A conceptual and operational analysis of these definitions enabled describing them in a concrete, measurable and objectively codifiable way. The findings from reading the selected articles gave rise to concepts in reference to etiological factors and clinical indicators and their respective conceptual and operational definitions, related to the diagnostic construct of low self-efficacy to be defined within a NANDA-I diagnostic label ${ }^{(13)}$.

\section{Construction of the pictorial diagram}

To make it easier to understand the middle-range theory, a pictorial diagram was created in order to graphically represent the main concepts found in the literature review, graphically explaining the interrelationships between the background factors, the phenomenon being studied and the clinical manifestations in the individual with low self-efficacy, with the support of the clinical reasoning of a nursing diagnosis ${ }^{(13)}$.

\section{Construction of proposals}

Based on the clinical reasoning and pictorial diagram, proposals were formulated to describe the relationships between the explanatory elements of the middle-range theory. The number of proposals for the concepts related to low self-efficacy in health depended on the findings obtained through the literature review. This analysis enabled identifying causal relationships for predicting the phenomenon of low self-efficacy in health as a diagnostic manifestation ${ }^{(13)}$.

\section{Establishment of causal relationships and evidence for clinical practice}

The last stage established and described the causal relationships between the elements that comprised the nursing diagnosis of low self-efficacy in health. To perform an optimum analysis of these relationships, the causal models suggested by Lopes, Silva and Herdman were applied ${ }^{(13)}$. These are classified into models: linear, trigger, domino effect, butterfly effect, leap in quality and sufficient causes. Each one of the models permitted an examination of the concrete clinical evidence and the connection between the literature review findings and the clinical reality ${ }^{(13)}$.

\section{RESULTS}

The search in the literature for elements associated with the clinical manifestation of a low level of self-efficacy in health occurred in two steps. First, 12,316 citations were identified in the four electronic databases. No searches for references were conducted in gray literature. After a thorough review of the titles and duplicates, 12,020 were excluded and 296 were chosen for reading their abstracts and application of the inclusion criteria, resulting in the elimination of 198 references. In sum, 98 selected articles remained for a full text reading (second step). This process resulted in the exclusion of six studies. A total of 92 articles were selected for extraction of concepts (Figure 1).

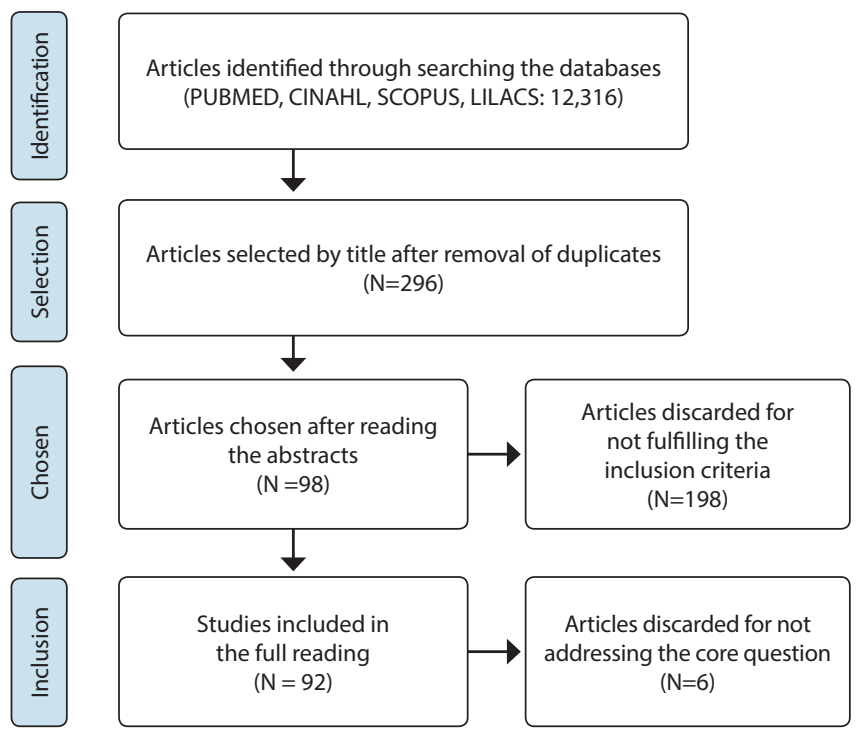

Figure 1 - Flowchart of the stages of the systemic review of the primary articles selected for elements associated with low self-efficacy in health

\section{Definition of the main concepts}

After the articles chosen in the previous stage were read, a conceptual and operational analysis was performed on the different terms reported by the authors in relation to the triggers and clinical manifestations of a low level of self-efficacy in health. The key concepts in this study for validating the new nursing diagnosis were: low level of self-efficacy in health according to NANDA-I (etiological factors and clinical indicators). These main concepts were then classified into cognitive, emotional and behavioral components, based on Bandura's self-efficacy theory. They were also sorted by physiological and sociodemographic factors (the latter, only for the etiological factors), described empirically in the reviewed literature as components that influence the manifestation of a low level of self-efficacy in health (Charts 1 and 2).

Chart 1 - Classification of concepts related to the presentation of a low level of selfefficacy in health

\begin{tabular}{|c|c|c|c|c|}
\hline \multicolumn{5}{|c|}{ Etiological factors of the nursing diagnosis of low self-efficacy in health } \\
\hline Cognitive & Emotional & Physiological & Socioeconomic & Behavioral \\
\hline \multirow{2}{*}{$\begin{array}{l}\text { Perception } \\
\text { of serious } \\
\text { consequences } \\
\text { of the } \\
\text { disease }^{(15)}\end{array}$} & \multirow{2}{*}{$\begin{array}{l}\text { Feelings of } \\
\text { lack of trust } \\
\text { in health } \\
\text { professionals(6) }\end{array}$} & \multirow{2}{*}{$\begin{array}{l}\text { Greater } \\
\text { health status } \\
\text { impairment } \\
\text { due to } \\
\text { severity of the }_{\text {disease }}{ }^{(15)}\end{array}$} & $\begin{array}{l}\text { Insufficient } \\
\text { social support }\end{array}$ & \multirow[t]{6}{*}{$\begin{array}{l}\text { Impaired verbal } \\
\text { communication (28) }\end{array}$} \\
\hline & & & $\begin{array}{l}\text { Low } \\
\text { educational } \\
\text { level }^{(27)}\end{array}$ & \\
\hline $\begin{array}{l}\text { Perception of } \\
\text { barriers }^{(16)}\end{array}$ & Fear $^{(20)}$ & Fatigue $^{(22)}$ & \multirow[t]{4}{*}{$\begin{array}{l}\text { Poor economic } \\
\text { situation }^{(27)}\end{array}$} & \\
\hline $\begin{array}{l}\text { Knowledge } \\
\text { deficits }^{(17)}\end{array}$ & $\begin{array}{l}\text { Feelings of } \\
\text { impotence }\end{array}$ & Age limits ${ }^{(23)}$ & & \\
\hline $\begin{array}{l}\text { Compensatory } \\
\text { health beliefs }^{(18)}\end{array}$ & \multirow[t]{2}{*}{ Anxiety ${ }^{(6)}$} & Stress ${ }^{(24)}$ & & \\
\hline $\begin{array}{l}\text { Experiencing } \\
\text { failure }^{(19)}\end{array}$ & & Pain $^{(25)}$ & & \\
\hline
\end{tabular}


Chart 2 - Classification of concepts related to the clinical manifestation of a low level of self-efficacy in health

\begin{tabular}{|c|c|c|c|}
\hline \multicolumn{4}{|c|}{ Clinical indicators of the nursing diagnosis of low self-efficacy in health } \\
\hline Behavioral & Cognitive & Emotional & Physiological \\
\hline $\begin{array}{l}\text { Risk prone health } \\
\text { behavior( }^{(29)}\end{array}$ & Lower quality of life $\mathrm{e}^{(10)}$ & Feelings of anger ${ }^{(38)}$ & \multirow[t]{9}{*}{$\begin{array}{l}\text { More complaints } \\
\text { about pain }\end{array}$} \\
\hline Low adherence $\mathrm{e}^{(30)}$ & Insufficient self-contro|(36) & \multirow{8}{*}{$\begin{array}{l}\text { Denial of changes in } \\
\text { health status }{ }^{(27)}\end{array}$} & \\
\hline Co-dependency ${ }^{(31)}$ & $\begin{array}{l}\text { Lower degree of health } \\
\text { empowerment }^{(22,37)}\end{array}$ & & \\
\hline $\begin{array}{l}\text { Lack of interest in } \\
\text { improving health } \\
\text { behaviors }^{(27)}\end{array}$ & \multirow[t]{6}{*}{ Low self-perception of health ${ }^{(24)}$} & & \\
\hline $\begin{array}{l}\text { Failure to act to } \\
\text { prevent health } \\
\text { problems } \\
\text { (32) }\end{array}$ & & & \\
\hline Self-care deficit ${ }^{(17,33)}$ & & & \\
\hline $\begin{array}{l}\text { Reduced problem- } \\
\text { solving ability(10) }\end{array}$ & & & \\
\hline $\begin{array}{l}\text { Avoidance } \\
\text { behavior }^{(34-35)}\end{array}$ & & & \\
\hline $\begin{array}{l}\text { Impaired verbal } \\
\text { communication }^{(6)}\end{array}$ & & & \\
\hline
\end{tabular}

\section{Construction of the pictorial diagram}

Using the key concepts found in the literature review, a pictorial diagram was prepared in order to graphically explain the interrelations between the main concepts of the phenomenon according to the following characteristics: antecedents and clinical manifestation in individuals with low self-efficacy ${ }^{(13)}$. A cause and effect diagram, also called a fishbone or Ishikawa diagram, was prepared. This technique enables performing an analysis of a phenomenon, its link to the corresponding causes and its effects or manifestations (Figures 2 and 3).

The main concepts described empirically in the reviewed literature as factors that influence the manifestation of a low level of selfefficacy were qualified and grouped into cognitive, emotional, physiological, behavioral and socioeconomic components. These findings coincided with Bandura's proposal as being the main components that interact in triadic reciprocity ${ }^{(2)}$, in a person-behavior-environment; the person determined by his or her cognitions, emotions and biological factors, together with behavior and environment. Bandura's theory explains how human beings transform the environment by changing their behavior. However, individuals with low self-efficacy cannot modify their environment because they believe they are unable to change their behavior ${ }^{(33)}$.

The cognitive components that deal with the knowledge and accumulation of information obtained through the learning processes and experiences of each individual, include internal factors experienced by the subject $^{(39)}$, as well as the emotional concepts individuals experience in the face of difficult situations and that influence their belief in their operational capabilities ${ }^{(40)}$. The behavioral component refers to the set of actions taken by human beings to respond to a situation, the behaviors they adopt and how they behave in the presence of external factors ${ }^{(41)}$. There are also physiological factors involving the reaction to what the body produces in response to stimuli ${ }^{(42)}$ and, finally, socioeconomic factors that affect self-perception and self-efficacy (the latter is only reported within the etiological factors).
ETIOLOGICAL FACTORS OF LOW SELF-EFFICACY IN HEALTH

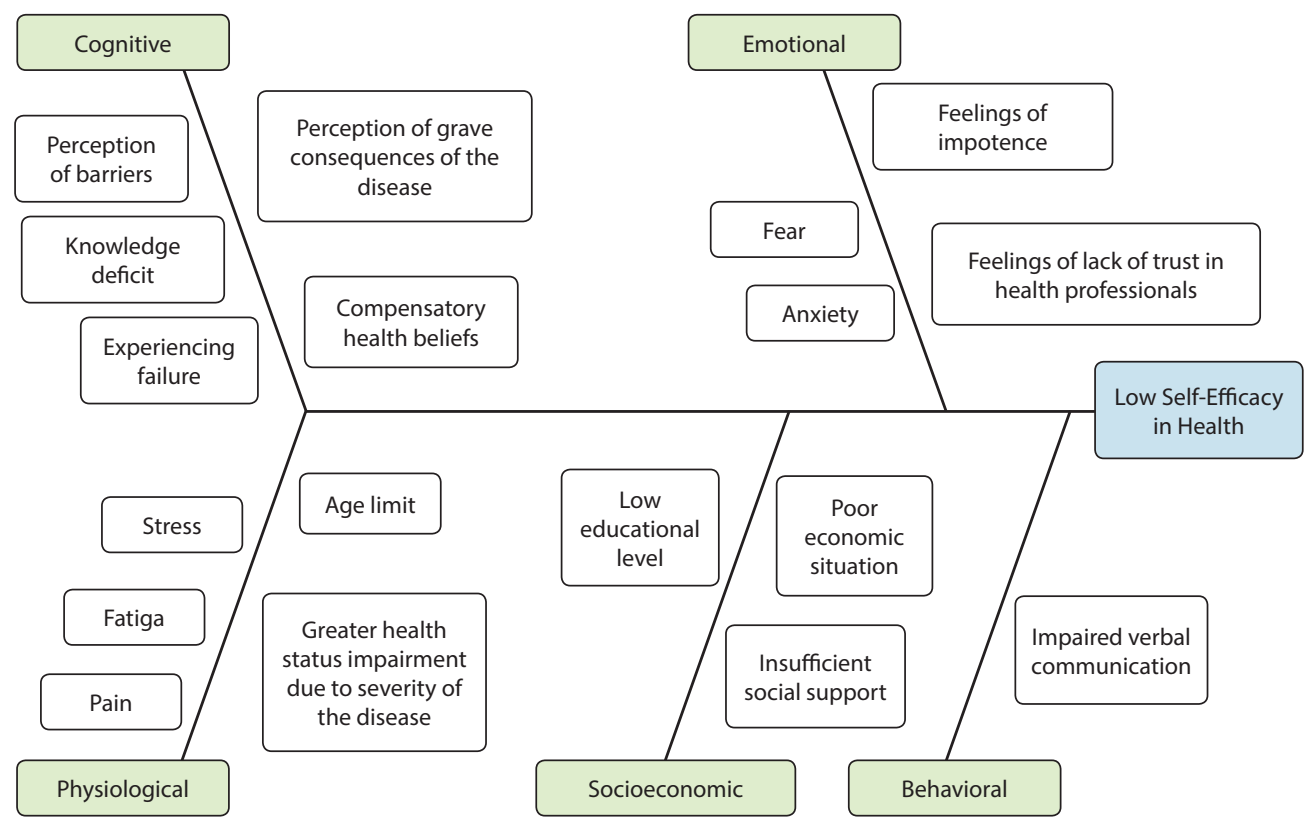

Figure 2 - Cause and effect diagram of etiological factors of a low level of health self-efficacy 


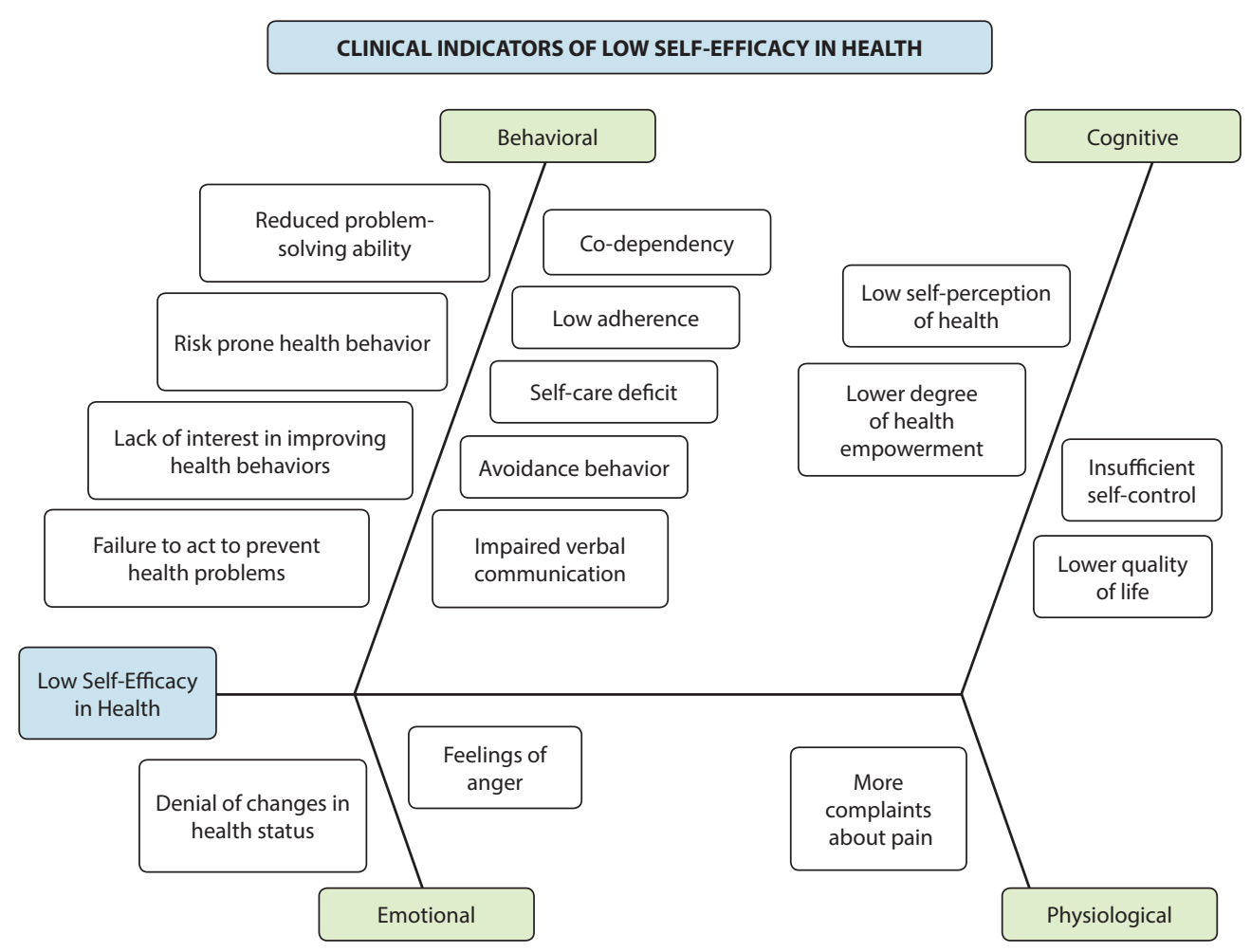

Figure 3 - Cause and effect diagram of clinical manifestations of a low level of health self-efficacy
- The only behavioral factor corresponds to impaired communication ${ }^{(28)}$, which leads to low self-efficacy because it hinders acquisition of information, knowledge and answers to questions, which are necessary elements for understanding the objectives of the actions that should be adopted to cope with a pathological process and promote one's health status $^{(17)}$.

- Negative socioeconomic factors are conducive to the manifestation of low selfefficacy in health, which are reinforced by a low level of education and lack of social support. These factors affect the level of knowledge and support for strengthening confidence in one's abilities to initiate and maintain actions for restoring health ${ }^{(26-27)}$.

\section{Construction of proposals}

After performing a clinical analysis of the key concepts and preparing the pictorial diagram, proposals were formulated to describe the relationships among the explanatory concepts of the middle-range theory on low self-efficacy in health ${ }^{(13)}$.

\section{Proposals for etiological factors}

- The concepts that comprise the etiological factors of a low level of self-efficacy can be classified into cognitive, emotional, physiological, behavioral and socioeconomic components.

- Cognitive components can lead to a manifestation of low self-efficacy in health ${ }^{(15-16)}$ because the variation in these phenomena alters the processes of cognitive self-assessment and affects self-confidence and patients' perception of their ability to face their health status-related problems ${ }^{(30-42)}$.

- The presence of emotional factors induces a low level of self-efficacy, since negative emotions and feelings have an impact on the self-judgments of individuals regarding their ability to adopt the necessary behaviors to restore their health ${ }^{(20,25)}$.

- The physiological factors are normal physical responses to aging and suffering from a disease, which undermine confidence in one's ability to confront a pathological process ${ }^{(25,36)}$.

- Symptoms, such as the pain and fatigue caused by a pathological event, can be interpreted by individuals as signs of weakness that render them incapable of performing actions to control unpleasant symptoms ${ }^{(23-24)}$.

\section{Proposals for clinical manifestations}

- The concepts corresponding to clinical manifestations of a low level of self-efficacy in health can be classified into behavioral, cognitive, emotional and physiological components.

- There are a significant number of clinical manifestations of low self-efficacy related to the behavioral component, reflecting that low perception of abilities to ensure optimum health can be identified by the presence of behaviors that expose individuals to a greater risk of acquiring a certain disease.

- Low self-efficacy is also manifested by the absence of behaviors that promote an adequate health status.

- A behavioral factor that can result in low self-efficacy in health ${ }^{(22,29)}$ is the lack of decisive actions for achieving adequate control over situations that individuals perceive as threats (disease). Therefore, the behaviors they need to adopt to address the pathological process are done in an inefficient way ${ }^{(37)}$.

- Impaired verbal communication was the only behavioral factor that was also an antecedent, which demonstrates that it may be manifested cyclically as a predisposing factor and clinical manifestation of low self-efficacy in health ${ }^{(6)}$.

- Changes of a cognitive nature are clinically manifested by the presence of a low level of self-efficacy in health, due to changes in cognitive skills for formulating positive perceptions of their ability to face a disease.

- Cognitive indicators that express low self-efficacy ${ }^{(10,24)}$ can be identified in perceptions of incompetency in choosing 
and maintaining certain courses of action and lack of control to make effective changes in their behavior in order to restore an optimum health status ${ }^{(22)}$.

- Clinical manifestations of an emotional nature indicate a low level of confidence in one's ability to carry out actions to ensure health and is reflected in disinterest and apathy toward one's personal health ${ }^{(19,27)}$.

- A low level of self-efficacy in health is manifested by changes of a physiological nature, translated into symptoms of changes in health status. People with low self-efficacy feel they cannot do anything to control the symptoms or the factors that trigger pain, due to their personal impotence and incapacity ${ }^{(21)}$.

\section{Establishment of causal relationships and evidence for clini- cal practice}

Through analyzing the pictorial diagram of the elements obtained from the integrative literature review, it can be inferred that there are various elements that can lead nurses to diagnose low self-efficacy in health among individuals in their care. Twenty etiological factors and 19 clinical indicators were identified and grouped into cognitive, emotional, behavioral, physiological and socioeconomic components. Behavioral and cognitive components were more frequently present in clinical manifestations and, with respect to the etiological factors, cognitive and emotional concepts were more common.

\section{Establishment of casual relationships in clinical manifestations}

In relation to clinical as manifestations, the behavioral component is the most relevant because individuals modify their behavior through a system of internal criteria that determine, organize and control conduct. Therefore, when a low level of selfefficacy exists, this can be identified by the presence of behaviors that expose people to risk factors, as well as by the absence of behaviors that promote health ${ }^{(2)}$.

Among the behavioral components indicating low self-efficacy in health were phenomena related to the ability to manage problems generated by pathological processes: risk-prone health behavior $^{(4,29)}$ lack of interest in improving health behaviors ${ }^{(27)}$, failure to act to prevent health problems ${ }^{(32)}$, reduced problem-solving ability ${ }^{(10)}$, codependency ${ }^{(31)}$ and avoidance behavior ${ }^{(34-35)}$. It can be noted that low confidence and negative perceptions regarding one's abilities are reflected in harmful behaviors, which are not consistent with appropriate activities for promoting health.

In addition to the previous clinical manifestations of a behavioral nature, low adherence to pharmacological or non-pharmacological treatment is an important behavioral indicator reported by various authors $^{(30,37)}$, evidenced by changes in perception and belief in one's ability to complete a therapeutic regimen ${ }^{(5,42)}$. Low adherence is a sign that helps identify low self-efficacy in health ${ }^{(30)}$, since inadequate adherence to a therapeutic regimen reflects inability and lack of commitment to carry out treatment ${ }^{(5)}$. This concurs with Bandura's social cognitive theory, which establishes that behavioral components reflect whether individuals are capable of starting, exerting themselves and persevering in a specific behavior ${ }^{(2)}$.
Another behavioral component that indicates a low level of self-efficacy is impaired verbal communication ${ }^{(6)}$, manifested in more conservative patients who are uninterested in dispelling doubts and obtaining information to understand how to deal with a change in health. A final clinical manifestation of low self-efficacy is a self-care deficit ${ }^{(17)}$, since patients with a low perception of their abilities have less motivation and do not trust in their abilities to successfully implement self-care measures ${ }^{(33)}$.

With respect to cognitive clinical manifestations of low selfefficacy in health, they are relevant since self-efficacy is a cognitivebehavioral construct. Therefore, cognitions can have an impact on the behaviors that people adopt ${ }^{(28)}$. Among these cognitive factors are those of a perceptual nature which include low selfperception of health ${ }^{(24)}$ and perception of lower quality of life ${ }^{(10)}$.

A low level of self-efficacy is manifested by how individuals perceive themselves in the face of a disease or change to their health status. A perception of low self-efficacy impairs the cognitive process which, in turn, affects how people interpret their level of competence ${ }^{(31)}$, and is also expressed in lack of confidence in the necessary abilities and skills for coping with a pathological process $^{(24)}$.

Similarly, a clinical manifestation of low self-efficacy is also evidenced by other types of cognitive elements, particularly related to abilities, leading patients to feel incompetent to carry out specific actions, which is reflected in a lower degree of health empowerment $^{(22,37)}$ and insufficient self-control ${ }^{(36)}$. It can be deduced that changes in self-efficacy are expressed in an inability to take control and be confident in one's ability to implement the necessary actions for obtaining a desired outcome ${ }^{(32)}$. In the context of health, this means adopting behavior to care for one's well-being and control factors underlying the disease.

On the other hand, a diagnosis of low self-efficacy in health can be identified through emotional factors expressed in feelings of anger ${ }^{(38)}$. This clinical manifestation reflects the frustration that patients experience when they find themselves unable to follow a course of action. Another etiological emotional factor is denial of one's health status ${ }^{(21)}$, which serves as a defense mechanism for patients, invalidating disagreeable and unwanted information about their lives. It was found that perceptions of low self-efficacy are manifested by emotions and feelings that negatively influence courses of action that need to be implemented to restore one's health ${ }^{(2)}$.

Finally, a physiological component found in the literature which indicates a low level of self-efficacy in health corresponds to more complaints about pain ${ }^{(25)}$. This demonstrates that lack of belief one's ability to manage pain and carry out activities despite persistent pain is an important manifestation of the perception of inability to control factors stemming from this pain ${ }^{(36)}$.

\section{Establishment of casual relationships among etiological factors}

In the analysis of the etiological factors and clinical antecedents, cognitive components stand out in terms of low self-efficacy in health, confirming Bandura's theoretical assumptions ${ }^{(32)}$ that cognitions affect the behavior adopted by individuals. Among the components related to cognitions, the following factors of a perceptual nature are particularly noteworthy: perception of 
serious consequences of the disease ${ }^{(36)}$ and perception of barriers $^{(16)}$. These factors can affect the judgments people make about their ability to carry out actions and engage in certain behaviors ${ }^{(2,37)}$. In effect, they believe that the actions they should take to restore their health are unreachable and that the barriers for putting these behaviors into practice are insurmountable.

In addition to the previous etiological factors of a cognitive nature that favor the manifestation of low self-efficacy in health, there are elements that affect the process for learning new information needed by individuals to confront pathological processes. One element, in particular, is knowledge deficit ${ }^{(17)}$, which affects understanding and is reflected in lack of information and disinterest in seeking the necessary information ${ }^{(38)}$ for understanding the importance of taking action to deal with a disease, generating an inability to make decisions and implement measures for improving health ${ }^{(17)}$.

In relation to other etiological factors of a cognitive nature, experiencing failure ${ }^{(19)}$ is a relevant antecedent in the manifestation of low self-efficacy in health, since these experiences give rise to frustration and individuals consequently develop a mindset of incompetence regarding what they attempted to implement, but where the results were different than expected ${ }^{(40)}$. These negative experiences affect their perception of their ability to carry out future actions.

Finally, among the etiological factors of a cognitive nature, are compensatory health beliefs ${ }^{(18)}$. These elements can lead to a low level of self-efficacy in health by instilling in individuals beliefs that an unhealthy behavior can be offset by another that is healthy, which interferes with understanding the risk involved in not controlling behavior that is harmful to health and the importance of carrying out effective actions to restore their well-being ${ }^{(43)}$.

Another type of etiological factor for low self-efficacy in health corresponds to emotional concepts, which include disagreeable emotional states which people experience when facing a change in their health status: anxiety ${ }^{(6)}$ and fear ${ }^{(20)}$. These factors have an impact on self-efficacy in health, because individuals experience a sensation of threat, due to the consequences of suffering from a disease, resulting in a loss of ability to direct their actions when facing pathological processes. This undermines their confidence in their capabilities to implement actions to care for their health.

Continuing with etiological factors of an emotional nature, it was found that feelings of impotence ${ }^{(21)}$ arise in individuals suffering from a disease. This phenomenon is common in selfefficacy in health when people experience feelings of incapacity, limitations, lack of strength or ability to carry out actions to care for their health, in the face of a disease. Therefore, individuals believe that other people should compensate this lack of care that they are incapable of providing themselves.

Finally, among the clinical antecedents of an emotional nature, related to feelings that are prone to inciting a low level of selfefficacy in health, was the phenomenon of feelings of lack of trust in health professionals ${ }^{(6)}$. Such mistrust interferes negatively in the patient-provider interaction, where health professionals are agents of change, meant to help people modify their behavior through providing information and guidance, aimed at strengthening the capabilities of individuals to care for themselves and promote their health(44).
The physiological responses that people experience when facing pathological processes are another type of etiological factor indicative of low self-efficacy in health, including fatigue ${ }^{(22)}$, stress $^{(24)}$, pain ${ }^{(25)}$ and greater commitment to their health due to the severity of the disease ${ }^{(15,36)}$. The above factors engender feelings of hopelessness when individuals interpret the symptoms and the extent of the disease as signs of personal weakness, which creates perceptions of inability to execute cognitive strategies to control the symptoms caused by the disease, such as pain, or take intercessory actions to reduce stress.

Age limits are another type of physiological factor ${ }^{(23)}$. These antecedents influence the manifestation of low self-efficacy in health due to the lack of experience that younger people have in overcoming difficult circumstances, such as coping with a disease ${ }^{(45)}$. This also happens to older people and even though they may have had previous experience dealing with a disease, they now believe they do not have enough strength, nor do they trust in their ability to carry out the necessary actions to restore their health ${ }^{(46-47)}$.

In sum, the socioeconomic component was found in the empirical evidence as an etiological factor of low self-efficacy in health, corresponding to insufficient social support ${ }^{(26)}$, low educational level and a poor economic situation ${ }^{(27)}$. These antecedents contribute to the manifestation of inefficacy and beliefs of being unable to assume commitments to care for one's health, because people with lower levels of education, combined with lack of social support, view themselves as lacking the cognitive tools to better understand the information concerning the health changes they are facing. Nor do they have the support of a social circle to strengthen their confidence to take care of their health.

The only component of a behavioral nature found to be an etiological factor of low self-efficacy in health was impaired verbal communication $^{(6,28)}$. This has an effect on self-efficacy because it encumbers the interaction between the health provider and patient and interferes with acquisition of information, knowledge and clarifications regarding actions that must be taken and, therefore, understand the importance of committing to implementing the necessary measures to restore one's health ${ }^{(6)}$.

\section{Study limitations}

A limitation of this study was that the construct of self-efficacy is a very broad concept, applied in different contexts and not only in the area of health. Therefore, the number of articles in the databases was considerable and the selection of articles focused on studies that responded to the phenomena that explained the manifestation of a low level of self-efficacy in health specifically. This aspect did not affect the results of the study.

\section{Contributions to nursing knowledge}

This middle-range theory makes an important contribution to furthering the research on low self-efficacy in health, as well as to clinical practices, since it provides a useful tool for nursing professionals to efficiently detect signs of perceptions and expectations of personal inefficacy in patients. Therefore, the results of this theory can provide the basis for moving forward 
with new stages of research to empirically prove/study the identified concepts, in order to proceed with validation of content and clinical validation of this new nursing diagnosis.

\section{CONCLUSIONS}

The concepts related to the new nursing diagnosis of low selfefficacy in health, described in the scientific evidence to be applied in clinical practice, were identified through the middle-range theory methodology. The characterization of these concepts in the review of studies based on Bandura's social cognitive theory of self-efficacy enabled classifying these concepts into factors that lead to an outcome, i.e., in antecedents or manifestations of clinical signs indicating the presence of a low level of self-efficacy in the context of health.
The underlying factors and clinical manifestations of low self-efficacy in health that were identified correspond to cognitive, behavioral, emotional, physiological and to a lesser extent socioeconomic factors - elements that can be explained by the fact that individuals fail to adhere to the recommendations given by nurses and do not adopt the necessary behaviors for confronting a pathological process and/or engage in actions to promote their health.

\section{FUNDING}

This study had the financial support of the National Council of Scientific and Technological Development (CNPq) Process No. 305880 / 2018-7 and No141060 / 2018-2.

\section{REFERENCES}

1. Bandura A. Social foundations of thought and action: A social cognitive theory. Englewood Cliffs, NJ: Prentice-Hall, Inc. 1986.

2. Bandura A. Self-efficacy: The exercise of Control. New York: Freeman; 1977.

3. Sheer, Vivian C. A meta-synthesis of health-related self-efficacy instrumentation: problems and suggestions. J Nurs Meas. 2014;12;22(1):7793. doi: 10.1891/1061-3749.22.1.77

4. Bonner JE, Esserman DA, Golin CE, Evon DM. Self-efficacy and adherence to antiviral treatment for chronic hepatitis C. J Clin Gastroenterol. 2015;49(1):76-83. doi: 10.1097/MCG.0000000000000055

5. Andrade B, Céspedes V. Adherencia al tratamiento en enfermedad cardiovascular: rediseño y validación de un instrumento. Enferm Universit. 2017;14(4):266-76. doi: 10.1016/j.reu.2017.10.001

6. Finney Rutten LJ, Hesse BW, St-Sauver J, Wilson P, Chawla N, Hartigan DB, et al. Health self-efficacy among populations with multiple chronic conditions: the value of patient-centered communication. Adv Ther. 2016;33(8):1440-51. doi: 10.1007/s12325-016-0369-7

7. Guerrero J, Parra L, Mendoza J. Autoeficacia y calidad de vida en pacientes con diabetes mellitus tipo 2 sometidos a hemodiálisis. Rev Cubana Salud Pública [Internet]. 2016 [cited 2018 May 09];42(2):193-203. Available from: http://scielo.sld.cu/pdf/rcsp/v42n2/spu03216.pdf

8. Chew B, Fernández A, Shariff-Ghazali S. Psychological interventions for behavioral adjustments in diabetes care-a value-based approach to disease control. Psychol Res Behav Manag. 2018;4(11):45-155. doi: 10.2147/PRBM.S117224

9. Bandura A, Gurgel Ar, Polydoro S. Teoría social cognitiva: conceitos básicos. Porto Alegre: Artmed: 2008.

10. Silva M, Hortense P, Napoleão A, Stefane T. Autoeficácia, intensidade de dor e qualidade de vida em indivíduos com dor crônica. Rev Eletrôn Enferm. 2016;18:(e1145). doi: 10.5216/ree.v18.29308

11. Fawcett J. Middle-range nursing theories are necessary for the advancement of the discipline. Rev Aquichan [Internet]. 2005 [cited 2018 May 19];5(1):32-43. Available from: http://www.scielo.org.co/pdf/aqui/v5n1/v5n1a04.pdf

12. Fawcett J, Garity J. Evaluation of Middle Range Theories (Chapter 6). In Evaluating Research for Evidence-Based Nursing Practice. FA Davis; 2009.

13. Lopes MV, Silva VM, Herdman TH. Causation and Validation of Nursing Diagnoses. Int J Nurs Terminol Knowledge. 2015;28:53-59. doi: $10.1111 / 2047-3095.12104$

14. Brandão M, Martins J, Peixoto M, Lopes R, Primo C. Reflexões teóricas e metodológicas para a construção de teorías de médio alcance de enfermagem. Texto Contexto Enferm. 2017;26(4):e1420017. doi: 10.1590/0104-07072017001420017

15. Zelber-Sagi S, Bord S, Dror-Lavi G, Smith ML, Towne Jr SD, Buch A, et al. Role of illness perception and self-efficacy in lifestyle modification among non-alcoholic fatty liver disease patients. World J Gastroenterol. 2017;23(10):1881-90. doi: 10.3748/wjg.v23.i10.1881

16. Meuleman Y, Hoekstra T, Dekker F, Van Der Boog P, Van Dijk S, Study. GE. Perceived sodium reduction barriers among patients with chronic kidney disease: which barriers are important and which patients experience barriers? J Behav Medicine. 2018;25(1):93-102. doi: 10.1007/ s12529-017-9668-x

17. Bailey RA, Pfeifer M, Shillington AC, Harshaw Q, Funnell MM, Vanwingen J, et al. Effect of a patient decision aid (PDA) for type 2 diabetes on knowledge, decisional self-efficacy, and decisional conflict. BMC Health Serv Res. 2016;16(10):2-14. doi: 10.1186/s12913-016-1262-4

18. Storm V, Reinwand D, Wienert J, Kuhlmann T, De Vries H, Lippke S. Brief report: Compensatory health beliefs are negatively associated with intentions for regular fruit and vegetable consumption when self-efficacy is low. J Health Psychol. 2017;22(8):1094-100. doi: $10.1177 / 1359105315625358$

19. Cafazzo JA, Leonard K, Easty AC, Rossos PG, Chan CT. Patient-perceived barriers to the adoption of nocturnal home hemodialysis. Clinl J Am Soc Nephrol. 2009;4(4):784-9. doi: $\quad$ 10.2215/CJN.05501008 
20. Schwartz L, Toohill J, Creedy Dk, Baird K, Gamble J, \& Fenwick J. Factors associated with childbirth self-efficacy in Australian childbearing women. BMC Pregnancy Childbirth. 2015;15(29):1-9. doi: 10.1186/s12884-015-0465-8

21. Sturrock BA, Xie J, Holloway EE, Hegel M, Casten M, Mellor D, Fenwick E, et al. Illness cognitions and coping self-efficacy in depression among persons with low vision. Invest Ophthalmol Vis Sci. 2016;57(7):3032-8. doi: 10.1167/iovs.16-19110

22. Armbrust W, Lelieveld OHTM, Tuinstra J, Wulffraat NM, Bos GJFJ, Cappon J, et al. Fatigue in patients with juvenile idiopathic arthritis: relationship to perceived health, physical health, self-efficacy, and participation. Pediatr Rheumatol O J. 2016;14(65):1-9. doi: 10.1186/ s12969-016-0125-1

23. Bay A, Sandberg C, Thilén U, Wadell K, Johansson B. Exercise self-efficacy in adults with congenital heart disease. IJC Heart Vascul. 2018;18:711. doi: 10.1016/j.ijcha.2017.12.002

24. Jamieson LM, Parker EJ, Roberts-Thomson KF, Lawrence HP, Broughton J. Self-efficacy and self-rated oral health among pregnant aboriginal Australian women. BMC Oral Health. 2014;14(29):1-7. doi: 10.1186/1472-6831-14-29

25. Brouwer S, Franche RL, Hogg-Johnson S, Lee H, Krause N, Shaw WS. Return-to-work self-efficacy: development and validation of a scale in claimants with musculoskeletal disorders. J Occup Rehab. 2011;21(2):244-58. doi: 10.1007/s10926-010-9262-4

26. Carballo NJ, Alessi CA, Martin JL, Mitchell MN, Hays RD, Col N, et al. Perceived effectiveness, self-efficacy, and social support for oral appliance therapy among older veterans with obstructive sleep apnea. Clin Therap. 2016;38(11):2407-15. doi: 10.1016/j. clinthera.2016.09.008

27. Yong HH, Siahpush M, Borland R, Li L, O'connor Rj, Yang J, et al. Urban Chinese smokers from lower socioeconomic backgrounds face more barriers to quitting: results from the international tobacco control - China Survey. Nicotine Tobacco Res. 2013;15(6):1044-51. doi: 10.1093/ ntr/nts234

28. Cruz AC, Angelo M, Santos BP. Self-efficacy scale for the establishment of good relationships with families in neonatal and pediatric hospital settings. Rev Esc Enferm USP. 2017;51:e03222. doi: 10.1590/s1980-220x2016033803222

29. Castro V, Benjet C, Juárez F, Jurado S, Lucio Gómez-Maqueo M, Valencia A. Non-suicidal self-injuries in a sample of Mexican university students. Salud Mental. 2017;40(5):191-200. doi: 10.17711/sm.0185-3325.2017.025

30. Berg KM, Cooperman NA, Newville H, Arnsten JH. Self-efficacy and depression as mediators of the relationship between pain and antiretroviral adherence. J Health AIDS Care. 2009;21(2):244-8. doi: 10.1080/09540120802001697

31. Mansyur C, Pavlik V, Hyman D, Taylor W, Goodrick G. Self-efficacy and barriers to multiple behavior change in low-income African Americans with hypertension. J Behav Medicine. 2013;36(1):75-85. doi: 10.1007/s10865-012-9403-7

32. Clum, GA, Rice, JC, Broussard, M, Johnson, CC, \& Webber, LS. Associations between depressive symptoms, self-efficacy, eating styles, exercise and body mass index in women. J Behav Medicine. 2014;37(4):577-86. doi: 10.1007/s10865-013-9526-5

33. Gutiérrez R, Gómez AM. Agencia de autocuidado y autoeficacia percibida en personas con cardiopatías isquémicas. Av Enferm. 2018;36(2):161-9. doi: 10.15446/av.enferm.v36n2.65674

34. Cho Y, Thrasher J, Yong H, Szklod A, O'connor Bt, D H, et al. Path analysis of warning label effects on negative emotions and quit attempts: a longitudinal study of smokers in Australia, Canada, Mexico, and the US. Soc Sci Medicine. 2018;197:226-34. doi: 10.1016/j. socscimed.2017.10.003

35. Umubyeyi A, Mogren I, Ntaganira J, Krantz G. Help-seeking behaviours, barriers to care and self-efficacy for seeking mental health care: a population-based study in Rwanda. Soc Psychiatr Psychiatr Epidemiol. 2016;51(1):81-92. doi: 10.1007/s00127-015-1130-2

36. Gruber-Baldini AL, Velozo C, Romero S, Shulman LM. Validation of the PROMIS ${ }^{\oplus}$ measures of self-efficacy for managing chronic conditions. Qual Life Res. 2017;26(7):1915-24. doi: 10.1007/s11136-017-1527-3

37. Náfrádi L, Nakamoto K, Schulz PJ. Is patient empowerment the key to promote adherence? A systematic review of the relationship between self-efficacy, health locus of control and medication adherence. PLoS ONE. 2017;12(10):e0186458. doi: 10.1371/journal.pone.0186458

38. Jones DL, Owens MI, Lydston D, Tobin JN, Brondolo E, \& Weiss SM. Self-efficacy and distress in women with AIDS: the SMART/EST Women's Project. AIDS Care. 2010;22(12):1499-508. doi: 10.1080/09540121.2010.484454

39. Capilla RM. Habilidades cognitivas y aprendizaje significativo de la adición y sustracción de fracciones comunes. Cuad Investigación Educ. 2016;7(2):49-62. doi: 10.18861/cied.2016.7.2.2610

40. Salvador CM, Morales J. Autoeficacia emprendedora en jóvenes mexicanos: ¿Cómo afecta la satisfacción vital y la inteligencia emocional percibida? Interam J Psychol [Internet]. 2009 [cited 2018 Mar 16];43(2):268-78 Available from: http://pepsic.bvsalud.org/pdf/rip/v43n2/ v43n2a08.pdf

41. Silva MAd. Terapia Cognitiva-Comportamental: da teoria à prática. Psico-USF. 2014;19(1):167-8. doi: 10.1590/S1413-82712014000100016

42. Fuentes Z, López S, Salazar M. Consideraciones de la respuesta fisiológica al estrés quirúrgico. Rev Cubana Anestesiol Reanimación[Internet]. 2014 [cited 2018 Nov 19];13(2):136-46. http://scielo.sld.cu/pdf/scar/v13n2/scar05214.pdf

43. McCauley E, Mullen SP, Szabo AN, White SM, Wójcicki TR, Mailey EL, et al. Self-regulatory processes and exercise adherence in older adults: executive function and self-efficacy effects. Am J Prev. 2011;41(3):284-90. doi: 10.1016/j.amepre.2011.04.014

44. Ramírez P, Müggenburg C. Relaciones personales entre la enfermera y el paciente. Enferm Univ. 2015;12(3):134-43. doi: 10.1016/j. reu.2015.07.004 
45. Piergiovanni LF, De Paula Pd. Estudio descriptivo de la autoeficacia y las estrategias de afrontamiento al estrés en estudiantes universitarios argentinos. Rev Mex Invest Educ[Internet]. 2018[cited 2019 Feb 27];23(77):413-32. Available from: http://www.scielo.org.mx/pdf/rmie/ v23n77/1405-6666-rmie-23-77-413.pdf

46. Tapia PC, Iturra MV, Valdivia RY, Varela VH, Jorquera CM, Carmona GA. Estado de salud y autoeficacia en adultos mayores usuarios de atención primaria en salud. Cienc Enferm. 2017;23(3)35-45. doi: 10.4067/S0717-95532017000300035

47. Sarkar U, Ali S, Whooley MA. Self-efficacy as a marker of cardiac function and predictor of heart failure hospitalization and mortality in patients with stable coronary heart disease: findings from the heart and soul study. Health Psychol Am Psychol Assoc. 2009;28(2):166-73. doi: $10.1037 / \mathrm{a} 0013146$ 